\title{
Social capital and the role of trust in aspirations for higher education
}

Article

Accepted Version

Fuller, C. (2014) Social capital and the role of trust in aspirations for higher education. Educational Review, 66 (2). pp. 131-147. ISSN 1465-3397 doi:

https://doi.org/10.1080/00131911.2013.768956 Available at https://centaur.reading.ac.uk/30599/

It is advisable to refer to the publisher's version if you intend to cite from the work. See Guidance on citing.

To link to this article DOI: http://dx.doi.org/10.1080/00131911.2013.768956

Publisher: Routledge

All outputs in CentAUR are protected by Intellectual Property Rights law, including copyright law. Copyright and IPR is retained by the creators or other copyright holders. Terms and conditions for use of this material are defined in the End User Agreement.

\section{www.reading.ac.uk/centaur}

\section{CentAUR}

Central Archive at the University of Reading

Reading's research outputs online 
Social Capital and Educational Aspirations

\title{
Social Capital and the Role of Trust in Aspirations for Higher Education (7,997 words)
}

\begin{abstract}
This paper considers the role of social capital and trust in the aspirations for higher education of a group of socially disadvantaged girls. Drawing on data from a longitudinal, ethnographic case study of an underperforming secondary school, the paper considers current conceptualisations of social capital and its role in educational ambitions. The paper concludes by tentatively suggesting that whilst social capital is extremely helpful in explaining differences within groups, trust appears to be a pre-requisite for the investment and generation of social capital, as opposed to the other way around. The paper also suggests that young people are not necessarily dependent on their families for their social capital but are able to generate capital in their own right.
\end{abstract}

Fuller, C. The Institute of Education, The University of Reading, UK

\section{Introduction}

In theory and policy discourse aimed at explaining and addressing persisting inequalities in the educational attainment and aspirations of students from different socio-economic backgrounds, the role and significance of various 'capitals' is consistently framed as key. In exploring these, both theory and policy emphasises the importance of families, as the endower of a student's capital, and the relationship of these capitals in educational outcomes. Policy therefore appears to be compensatory, attempting to re-dress some of the balance amongst families that are lacking in these resources. The greater an individual's social, cultural and economic capital, the greater their ability to access institutional resources, achieve educational success and so acquire further capitals. Students from poorer families, having less capital, are seriously disadvantaged; attaining less well and having lower 
educational aspirations as a consequence, than students from more socially advantaged backgrounds. In these terms, cultural, social and economic capital can perpetuate social inequalities within education and reproduces social disadvantage. Yet attempting to explain differential educational outcomes empirically using concepts such as social and cultural capital is problematic, not least because there are competing conceptualisations as to what does and does not constitute a social and cultural resource (Goldthorpe, 2007; Bogenschneider, 1997; Jenkins, 1992; Di Maggio, 1982). As some critics argue, an over reliance on the role of family in education can also ignore the important ways that schools can endow individuals with capital (Halsey, 1997) or, how young people acquire and accumulate capital in their own right, independent of families. Nevertheless and despite debate, the broad explanatory significance of 'cultural capital' (Bourdieu, in Halsey 1997) as a theoretical tool for explaining differences in educational outcomes has achieved some consensus. However, in more recent years there has been an increasing focus on the role of social capital in education: specifically, the ways in which civic engagement and community involvement can promote relationships of reciprocity and thus reinforce the values of school and impact on outcomes. In this paper I explore the value of social capital as a conceptual tool for explaining the educational aspirations of a group of socially disadvantaged girls in the UK, paying particular attention to the role that trust - key to conceptualisations of social capital - plays in the development of high educational aspirations. In particular, I consider the ways that social capital helps in explaining the aspirations of a small group of girls that aspired and then went on to university. It is hoped that by exploring theoretical understandings of social capital as a cultural resource, this paper will contribute to our understanding of the nature of social production and reproduction more broadly.

\section{Background}


Within the sociology of education different theories offer competing explanations for the ways in which the economic foundation of class influences educational outcomes and shapes educational aspirations. Whether the result of class shaped dispositions/habitus or a calculation of economic based risks, class is presented as an explanatory tool to understand and explain why children from different class backgrounds have different educational outcomes. Within this area social capital, as a theoretical concept, appears to be receiving increased attention and much more a focus within educational policy because of its perceived explanatory power. Social capital however is a slippery concept in that, just as with cultural capital, it is defined in a number of ways.

Before moving onto a discussion of social capital it is important to note that in his theorising of social capital, Putnam also refers to bonding and bridging ties; distinctive yet important components to the way that social capital is mobilised. Bonding relates to links between homogenous groups such as family and friends. These ties tend to be more inward looking (Paton, 2007) and therefore fairly restrictive. Bridging in contrast relates to much weaker links, but ones between socially heterogeneous groups. Bridging is considered crucial for 'getting ahead' (Paton, 2007:22) and offers a means to understand the ways that people are able to move outside their social sphere. In this sense, social capital works for the advantage of the individual rather than society as a whole. Considering the ways that these operate within social capital is important because clearly, bonding between groups who are similar will mean that the capital of some groups is more valuable and positive than others. In addition, when making use of bridging capital, some connection - however tenuous - is going to be essential. Trust would appear to be key in these links, particularly in the case of more fragile and weaker links. 
Broadly, social capital refers to 'sociability, social networks and social support, trust, reciprocity and community and civic engagement' (Morrow, 1999:744), that is, the social relationships between individuals, institutions and communities. Social relationships are important because they promote shared objectives and foster cohesive communities and more importantly, encourage trust. As well as collective benefits social capital has benefits for the individual. Research by Laureau, 1997; Ball, 2003, for example, suggests that families with high levels of social capital promote educational success. This is because families with strong relationships with community, in this case with schools, are more likely to promote and reinforce the attitudes and values of the school. For example, if a parent is involved in their children's school it is probable that they will value the work carried out there because they have some knowledge and understanding of it through opportunities to meet and talk with teachers and other school staff. Indeed a plethora of research suggests that children are less likely to drop out of school, truant or perform badly academically if their parents are involved in their education in some way. Thus, educational attainment is viewed as causally related to the social capital of a student's family because engagement with schools fosters trusting and reciprocal relationships that are educationally beneficial.

Whilst not conceptually as broad and ambiguous as cultural capital, there still exist a number of competing definitions as to what social capital actually is, which in some respects makes operationalising it empirically difficult. Coleman (1988) for example, defines social capital by its function and, like other capitals, sees it as productive because it creates outcomes that would not be possible otherwise. To illustrate, Coleman explored the role that the frequency of religious attendance had on school dropout rates and found that dropout rates were more than double for students who rarely attended religious institutions as opposed to students who 
did. For Coleman, social capital is thus a resource, provided by community via shared relationships to the social structure and the organisations within it. For example, strong relationships, in this case with religious institutions, provide obligations, expectations and trust which then serve as influential determinants of action. Applying these ideas to education, the acquired social capital within families, via their engagement with schools, consequently 'promotes attitudes, efforts and conception of self' (Coleman, 1987:38) which collude with schools to promote educational attainment. Research suggests that the social capital of middle class families is much more advantageous than those of the working class and is more beneficial in education. Thus the social capital of the middle class is of a higher level because of its potential to produce returns (Ball, 2003; Reay, 2004 etc.). Implicit in Coleman's conceptualisation then, is a possible explanation as to why, despite educational expansion and reform, educational outcomes between different social groups remain static (Goldthorpe, 1997). However, levels of educational attainment and participation in post-16 education continue to rise in the UK which makes clearly establishing a causal relationship between family levels of social capital and outcomes difficult.

Putnam (2000) in contrast, focuses on the role of individual (as opposed to community) relationships, trust and reciprocity in his understanding of social capital. Social capital for Putnam is a capital acquired through social networks (and the relationships within them) that emerges through civic engagement. Civic engagement promotes knowledge and shared norms, which generate trust that is highly beneficial for society, particularly in terms of democracy. Civic engagement refers to activities such as voting, membership of different groups and clubs, voluntary work etc. Civic engagement for Putnam is, as Edwards and Foley (2001) point out, not just an indicator of social capital, it is social capital. Thus, when considering education, civic engagement would refer to parental involvement within school, 
Social Capital and Educational Aspirations

for example, by serving as parent governors; as members of Parents and Teachers Associations etc. Engagement of this nature encourages and promotes trusting relationship between adult and institution which, as with Coleman's view, then supports the transference of the ethos of school to home. Understandably, the consequence in terms of educational aspirations for children from families with greater levels of social capital would be positive, with the implicit idea that it is the engagement that matters, not where an individual is situated within the social structure.

Whereas Coleman's indicators of social capital are centred within the family and Putnam's are external (Croll, 2004), both acknowledge the importance of social networks within the concept of social capital. Bourdieu (1997) offers an alternative framework for understanding social capital however, one which is conceptualised as a structural resource determined by class. For Bourdieu social capital is relational and works strongly in conjunction with cultural and economic capital. Membership of a network provides access to the collectively owned capital available within it which can then be mobilised to an individual's advantage. However, the size and value of the capital available within the network is determined by both size of the network and the socio-economic background of those within it. Accessibility to and accumulation of social capital is therefore not open to all and is not independent of economic or cultural capital; membership and access requires 'a minimum of objective homogeneity' (1997:51). For Bourdieu then, social capital is structured and classed and serves symbolically to promote social closure whilst reinforcing class boundaries. In terms of education, social capital can be seen as particularly important when attempting to negotiate the field of education (Ball, 2003). Research by Horvat; Weininger and Lareau (2003) demonstrated how middle class families were able to draw on a range of professional contacts for information and expertise when they wished to contest judgements by school officials, for 
example, in relation to special educational needs. Social capital is therefore intrinsically linked to educational ambitions and aspirations because of the interconnection between economic, cultural and social capital (Grenfell, James, Hodkinson, Reay and Robbins, 1997).

Social capital is a useful theoretical tool because 'by identifying certain aspects of the social structure, the concept of social capital constitutes both an aid in accounting for different outcomes at the level of individual actors and an aid toward making the micro-to-macro transitions' (Coleman, 1988:101). Thus, social capital provides an explanatory means by which to explain differences in individual educational aspirations and values, by considering these in relationship to social networks and the engagement of parents with schools. However some critics express concern that the arbitrary nature of social capital creates problems in applying and testing the concept empirically. Morrow (1999) also adds that Coleman's development of social capital, whilst popular with academics, is not adequately contextualised in terms of socio-economic history and that, along with Putnam's definition, is a concept that is 'gender blind and ethnocentric...imported from the USA without... attention to cross and inter-cultural differences' (1999:749). This is a very relevant critique. If strong community relationships have positive consequences educationally, then how can social capital adequately explain the disparity in terms of educational attainment amongst those from different ethnic backgrounds? In the UK for example, students from Pakistani and Bangladeshi backgrounds consistently underachieve at GCSE yet are a group who could be considered as high in social capital because of their strong family, religious and community ties. Morrow also notes that Coleman appears to implicitly advocate a theoretical model that is founded on assumptions associated with the nature of family structure, i.e. the 'norm' of the nuclear family. Such a theoretical stance appears to suggest that single mothers and other family types as not conducive to social capital. Implied is the idea that declining social 
capital and ensuing poor educational achievement; indeed all social ills, perhaps lay at the door of single mothers and fragmented families. Research by Croll (2004) also suggests that whilst social and economic influences do constrain and limit the resources families have available to use on behalf of their children, they are not solely determined by them. Finally, an over emphasis on the family and the influence of parents' social capital on their children's educational outcomes ignores the important point that children are autonomous individuals in their own right, capable of not only utilising the social capital of their parents but also of acquiring their own.

\section{Social Capital and Policy}

Similar to the No Child Left Behind Act, introduced in the USA in 2003, Every Child Matters: Change for Children in Schools (2003) emerged from the Children Act and has at its heart the ethos that education is the most effective way of raising young people from disadvantaged backgrounds out of poverty. It recognised the need for families, local communities and schools to work collaboratively together. Extended Schools: Access to Opportunities and Services for All (DfES, 2005) is a programme that offers a range of services and activities which aim to encourage young people to achieve their full potential. A key component of the programme is the opening up of schools to make them more accessible to the community. By offering a range of after schools activities, access to school facilities and the provision of parenting support and programmes, the implicit idea is that schools develop into a central feature of community life.

In many ways Extended Schools can be seen as utilising ideas associated with social capital. For Coleman (1988) these types of community relationships promote a sense of belonging, 
shared expectations and trust which in turn translate into a greater educational engagement of both student and parent. Extended Schools therefore are '...not only about tackling underachievement but are also about tackling the causes of underachievement' (DfES, 2:2005); with the implication being that promoting social capital helps. As well as Extended Schools, from September 2007, schools were required by law to promote community cohesion in a more formal manner (DfES, 2007). A targeted focus on community cohesion requires that school build links with local organisations, for example, different religious groups, the police etc., encourage and provide opportunities for students to engage in volunteer work, build links with local employers and create connections with others schools that reflect the diversity of society. Building on the original principles of Extended Schools, the specific focus of this directive on community cohesion appears to also address issues of social capital associated with Putnam's (2000) conceptualisation of the term.

Both theory and policy conceptualise social capital then, as a social good that if invested has positive consequences for the societies, communities and individuals who engage with one another. Such a policy position is undoubtedly problematic in that it assumes trust is already established and that there is already a willingness to engage. In addition, it is highly likely that those with high levels of social capital are more likely to engage with these initiatives and not those for whom the policies are more focused on. Both Coleman and Bourdieu view parents as key in mobilising the advantages of social capital for the educational benefit of their children, whilst theoretical consensus posits the promotion of trust as a key outcome of engagement with schools. This paper seeks to explore the concept of social capital. It seeks to consider how well associated ideas such as trust can be seen to offer some explanation of the 
educational aspirations of a group of socially disadvantaged girls who aspired and then went on to university.

\section{Methods}

Data were collected for a much larger study that sought to explore educational aspirations via a two year longitudinal research using the case study method. Data was collected by focusing on a setting where certain outcomes would be expected: an underperforming school on special measures where low academic achievements and consequently aspirations would be the expected norm; i.e. the deviant case approach was adopted (Patton, 2002). Data was then collected from deviations within the case; students with high aspirations. Data collection focused on experiences of school, relationships with family, peers and teaching staff as well as ambitions for the future. Initially the study hoped to explore the aspirations of both boys and girls. However, as the school with the social characteristics of interest was a single sex girls' school, this resulted in a focus on girls.

\section{The Context}

"Southwell" is a state secondary school located in an economically thriving town in the south east of England. However, the area of the town which the school serves is, as Ofstednotes an, 'area of high social deprivation' (2006), one of the twenty per cent most deprived nationally and the most deprived locally. In addition, the area is in the top ten per cent of areas most deprived nationally for education, skills and training and crime as well in the top 10 per cent of areas for income deprivation affecting children, according to the English Indices of Deprivation (2004). The school struggles with consistently low academic achievement rates 
Social Capital and Educational Aspirations

(some twenty \% lower than the national average for GCSEs at the time of commencing the study). Just after commencing field work "Southwell” was placed on Special Measures.

\section{Data Collection}

At "Southwell" school, data was collected from year ten and year twelve students. Year ten students were selected as they had just begun their GCSE's and their careers advisory sessions and were thus beginning to consider their futures. Year twelve students, having already made the decisions to remain in education, were beginning to consider their future careers. These students were followed for a period of two years, up until several months after the results of their GCSE and A Level exams and relied upon a variety of data collection methods that include: participant observation, focus groups, structured and semi-structured interviews. This multi-method approach was adopted with the view that it would provide much richer data than using one method alone. Participant observation in school was used to explore, first hand, the school practices of students and staff and was carried out in a variety of settings: year twelve student common area, staff room and main areas of the school e.g. during assemblies, lunch area and tutor group times. This permitted observations to be made during both structured and unstructured periods of the school day. Focus groups were used to explore students' perceptions of education and attitudes to schooling and to gain an initial sense of students' expectations and aspirations. Focus groups also proved useful in another way in that they gave students an opportunity to get to know me within a group setting prior to one to one interviews and enabled students to feel more confident and comfortable to meet with me alone. The information collected from the focus groups was used to direct in-depth, semi-structured interviews with students and was used to identify the value placed on education, students' expectations for themselves in terms of achievement and their life 
course, and how these views impacted on students' perception of themselves. Students participated in a minimum of two focus groups and most students were interviewed formally between one and three times. Data is drawn from unstructured conversations also.

\section{Sample}

Among volunteers, I initially obtained a sample of 45 volunteer students ( 26 in year ten and 19 in year twelve). Some of the original volunteers were lost from the study after only one meeting, whilst many more new students joined throughout the course of my time in school. In total, I met or spoke with some 63 students. These included a broad mix of high and under achieving students. Core students (25) were those students I spent a significant amount of time with and on whom I collected the most background information. The convenience sampling approach i.e. a sample drawn from those who were willing to participate amongst those to whom I had access (Cohen et al, 2001) does raise issues concerning potential differences between those students willing to participate and those who were not. However, initial reluctance from some students who were less engaged with school to take part was addressed when one of the key girls decided to 'see what it was like'. From the overall sample, 8 girls had ambitions for a university education and it is on these I focus in this paper. Of these 8 , all came from manual or unemployed households and had parents who had not completed a higher education. The attainment levels of these young women were mixed, with some high attainers and others less so. Of the 8,7 did go on to higher education.

\section{Measuring class}

The relationship between social class or socio-economic status (SES) and various aspects of educational participation and attainment has been a central feature of the sociology of education. It is also an important aspect of the questions being considered in this paper. As discussed, the school being studied serves a relatively disadvantaged part of the town in 
which it is located, although the town overall is prosperous. It is therefore likely that the girls who are the subject of this study will themselves come from relatively less advantaged social and economic backgrounds. However, this cannot be simply assumed.

There is a variety of approaches to classifying and measuring social class as discussed by, for example Crompton (1998). She distinguishes between what she calls the 'common sense' schemes such as the Registrar General's based upon a hierarchy of rewards and status, subjective scales of occupational rankings and schemes such as that of John Goldthorpe's CASMIN scheme (in Devine, 1997; Crompton, 1998) which attempt to address theoretical ideas in sociology (in particular those associated with Marx and Weber) and to incorporate notions of class relations. However, what all these schemes have in common is that they are based on occupation and that they incorporate a distinction between manual and non-manual occupations as one of the key dividing points in the scale. While non-manual occupations are sometimes sub-divided in class terms (including 'intermediate' classes and higher and lower managerial (Crompton, 1998; Rose and Pevalin, 2002)) manual occupations are normally described as 'working class' when class terminology is employed.

\section{Categorizing Students}

A key analytical category used in the study is that of aspirations. The girls included for this paper have been categorised as 'high' educational aspirers. The notion of aspiration is intertwined with a complex of other responses to education and other aspects of their lives including attitudes to school and aims for careers and family. In order to make sense of the emerging interview and other material, data was analysed both theoretically and empirically and was explored in terms of patterns. Adopting this approach was extremely useful as, after initially organising students along the lines of how they felt about school, clear themes and 
similarities began to emerge in other ideas referred to. For example, those that felt most negative about school also intended to leave at 16 , whilst those that were most positive also intended to go to university. However, whilst in general a coherent set of responses emerged in terms of patterns in attitudes and ideas, there was also a complexity of responses and attitudes, intentions and so on, that did not always fit together neatly. For example, not all students wanting to leave school at 16 were negative about education, whilst not all students intending a higher education were positive about school. Students varied in their levels of response to school rather than being in pro- and anti- school groups.

The one dimension on which girls could be clearly distinguished into groups was with regard to educational intentions at 16 and then at 18 . Consequently, students were classified into groups of 'low educational aspirers', 'middle educational aspirers' and 'high educational aspirers' on the basis of planning to leave at 16, planning to leave at 18 and planning to go on into higher education. Classifying students based on their intentions seemed the most appropriate approach, despite the complexity, because of the very clear differences amongst students that were evident in terms of what they actually intended to do. However as already noted, despite similarities, some variations were noted in ideas and attitudes and attitudes are undoubtedly complex. Thus, whilst aspirations are clearly reflective of intentions, the attitudes of students within groups should not be considered as very clear and distinct groups. Naturally the approach I have taken relies on researcher judgement. However, the approach of 'analytic induction' is what enabled my categories to emerge. Through this process several new themes also began to emerge as important, with trust appearing to be one of the key areas as it linked so significantly to formal and informal relationships. This led me back to the literature and a consideration of social capital. In this paper trust is understood to be the 'firm belief in the reliability, truth, or ability of someone or something...[and] ... acceptance 
Social Capital and Educational Aspirations

of the truth of a statement without evidence or investigation' (Oxford On-line dictionary, accessed 26/6/2012)

\section{Findings}

\section{Values}

The 'high aspiring' girls included in this research were largely positive about the value of education, saw doing well educationally as crucial to their future success and all aspired to go on to university. Whilst students who planned to leave school at either 16 or 18 varied in their attitudes to school and expectations for their future, 'high educational aspirers' trusted that 'hard work' paid off and would ensure educational success. 'High educational aspirers' reflect a firm belief in the principles of meritocracy, principals that are reflectively determined and base on their individual beliefs about the way society works. In addition, whilst higher education can be viewed as a natural progression for the academically able, for others it was a determined strategy for self-improvement, social promotion and future independence. Underpinning these ideas was a strongly articulated sense of trust and belief in meritocracy; that future educational success would be dependent on one's own efforts.

If you work hard enough, [everyone] can have the same opportunities and I am willing to do that...I can have opportunities because I am willing to work hard.

Emily, year 11, focus group, 2007 
The idea of trust in individual effort relating to positive outcomes was evident in a number of strategies that 'high educational aspirers' adopted to maximise their academic performance. Unlike the 'low' and 'middle' educational aspirers, 'high educational aspirers' were happy to seek out help when they did not understand, spend their own money on resources to support their learning, such as additional books, attend revision and top up classes after school and take time off from school, which was sanctioned by parents, to re-do assignments to achieve better grades:

I stayed up until 4.30 am last night, re-doing some of my English course work ...well, I had actually done it but I just wasn't happy with it so, I decided to redo it.

Stephanie, year 11, individual interview, 2008

Whilst taking time off from school was not condoned, suggestive in teachers comments was that they were aware that this happened and a tacit suggestion that for students achieving well, a blind eye was turned if it wasn't too regular. In addition to this, 'high educational aspirers' enjoyed, for the large part, good relationships with teachers and mostly trusted that teachers had their best interest at heart in terms of educational attainment, and had high expectations of them. Whilst this was not true for every teacher they were, for the large part, considered fair.

Like our English teacher. She treats us like we are college students. She'll talk to us like we are level to her and that's why I really enjoy her class

\section{Involvement with school}


Social Capital and Educational Aspirations

Probably the most striking feature of the high educational aspirers, a feature that clearly differentiated them from the other girls, was their willingness to be actively involved in the life of the school. The high aspiring girls were all involved, in one way or another in schemes such as; student mentoring, Millennium volunteers, heads of school houses and student council etc. Low and middle educational aspirers did not engage with school in this way. The following case study illustrates the ways that several of the young women (5) engaged in the political life of the school, adopting pro-active measures to get theirs', and fellow students', voices heard when more conformist methods failed:

\section{The Trouser Protest}

"Southwell's" school uniform policy prohibited the wearing of trousers. However, several of the high aspiring students believed the ruling archaic, discriminatory and not in line with the practice of other schools. Despite using the correct forum to air their views - the student staff council - the request for a re-think, according to students, was continually rejected by the headteacher. Two of the students therefore decided to take matters into their own hands and so organised a protest. To begin with they encouraged students to come into school for three days wearing trousers. The protest was largely unsuccessful in terms of numbers participating but successful in that the head took notice and was willing to meet and discuss the issue (previous requests for an appointment had failed). The headteacher informed the students she was willing to go with the collective consensus and so suggested that they conduct a small survey of all tutor groups on student opinion. The response was as expected. Students and many staff were overwhelmingly in favour of the wearing of trousers. However, the move to change the uniform rule was rejected by the head. Her justification was that she believed students had gone about making a case in the wrong way, arguing the issue should have been raised in the correct forum, via the student council. She then prohibited the issue to be 
discussed further, either with her or at any future Student Staff Committee Meetings. Other protests, she warned, would be punished. Students refused to let the matter drop and sought out the OfSTED inspectors when they came into school. They requested support and help and were successful. OfSTED inspectors criticised the school for disregarding a genuine issue with popular support, raised in an appropriate forum i.e. student/staff committee and urged the school to reconsider its position. This they did and, to the immense satisfaction of the students involved, pupils were at last permitted to wear trousers. Despite being successful, the students involved were clear that they would have persisted with the cause, "I was going to make a report and send it to the government if I had to" said Deborah, year 11. Students also claimed a similar victory in a long standing battle for substantial improvements to school toilets. Requesting help and support from the Ofsted inspector could be argued as a demonstration of a lack of trust in formal school procedures. However, it could equally be argued that it demonstrates a far broader trust that is perhaps more ideological and unbounded to context. In addition, it demonstrates more explicitly a belief in the views expressed around 'hard work paying off' discussed earlier in the paper.

High aspiring students express however, for the large part, a general satisfaction with their school and with the experiences that they have had there. Positive experiences inevitably mean that some students are happy to continue on in to the sixth form but this is not so for others. 5 'high educational aspirers' opted to continue their post-16 education elsewhere, despite the fact that this would require significant travel in some instances. This was explained as a tactical decision designed to broaden social landscapes and experiences as well as an enhancement for university applications later on. These motivations could partly be explained by their view of education per se, i.e. that educational success was a measure of 
this individual effort. Thus, whilst moving on is tinged with sadness and nostalgia, ambitions and aspirations drives and motivates these students to study elsewhere:

I have been really happy and although I wanna stay here and do my A levels I can't. I want to go somewhere new and meet new people. It's important to do that if you wanna go to university... because it shows that you can apply yourself.

Deborah, Year 11, individual interview, 2008

Deborah expresses explicitly her desire to study elsewhere and the advantages she feels this will have both in terms of experience and in meeting new people. Unlike the middle educational aspiring students, remaining in the familiar was not desirable as it offered nothing new. Opting for alternative places of study was not positioned as a lack of satisfaction in their current school but was much more about having access to opportunities for making new friends and, more importantly, as particularly useful for university applications. Rationalising their further educational choices in this way demonstrates well the planning applied to future pathways and the means that some students adopted to maximise their chances of achieving their goals. In addition, these are strategies devised autonomously, according to students, with little influence yet the support of parents and teaching staff. It could be argued that these girls, having developed a trust in the broad system of education feel comfortable and confident enough to be able to move from the familiar to the unfamiliar, in search of educational advantage. This is evident in opting for places of further study which were not the choices or destinations of their friends. Clearly students have picked up the message that these things matter but where students are getting this message is not clear in this research.

\section{Role of families}

Several of the high educational aspirers refer to their parents' lack of further educational experience as a motivating factor in their aspirations. However, rather than hinder or limit 
aspirations, that parents had not 'made the most of their education' is used as a source of encouragement for their daughters:

My parents encouraged me... 'cause they didn't go on themselves. So, they want me to go to university and get a good job

Sandra, year 12, individual interview, 2007

\author{
Because my dad didn't go [to university] and like, he's having a hard time \\ now, work wise; I wanna make sure it doesn't happen to me
}

Emily, year 11, individual interview, 2007

Despite lacking personal knowledge and experience of further education, having not attended themselves, the parents of high educational aspirers appear to recognise the value of further and, in particular, higher education. This is in contrast to middle and lower aspiring parents, who did not see higher education as worthwhile. Parents of high educational aspirers encouraged their daughters with enthusiasm and a desire to see their daughters achieve where they had not. Parents of 'higher educational aspirers' were not 'hands-on' or involved in the life of their daughter's school; with most not even attending Parents' Evening. Cultural capital theory has been used by some researchers to illustrate how different social classes are endowed with different levels of cultural resources which have impact on ability to provide meaningful involvement in terms of their children's education attainment (Lareau, 1997; Reay: 2005; 1998). However, whilst the parents of students in this study would be considered low in terms of the popular understandings of social capital and were indeed not able to offer much more than basic support, praise and encouragement, this does not appear to have been 
detrimental to the value students themselves placed on education nor to their aspirations and ambitions for higher education:

...they'll take an interest [in my education] if I take an interest in wanting them to know. Otherwise they just keep out of it because sometimes I just don't want them to know. But, sometimes if I say "hey dad can you read this English essay for me and correct the spelling" then he'll read it and he'll be like "yeah, well this is good" and he'll try and help me change it. So, they show an interest...

Emily, Year 11, individual interview 2007

It is possible to infer that parental interest towards a student's education has greater significance for these girls than parental involvement. Parental interest in this research appears to be significant because it demonstrates recognition of the value of education in a way that is perceived as more meaningful to the students included here. In this study, high educational aspirers also frequently alluded to the idea that relationships of 'respect' were important to them:

[Emily discussing her father]... we'll just sit there and have a chat and it's just really, really nice... he's not actually sat me down and told me "oh! do this and this and this!" but he listens to me and we have conversations about stuff and I treasure that so much and it's something that I could not live without.

Students' decisions and decision making, both within and outside of school, are respected and trusted by the parent. This is not to say that students have carte blanche choice over all 
aspects of their lives; rather families communicate and the views of family members are respected. This was a distinguishing feature as the 'low' and 'middle' educational aspirers tended to make decisions based on what their friends were doing or on the guidance of parents. For the girls discussed her there was very much a sense of supported autonomy within the family and in their choices. For example, decisions about what to study and where, were supported but not directed by parents. Li and Kerpelman (2007), in a study of parental influences on young women's career aspirations, discuss how daughters are often better prepared to make their own choices 'when they experience explicit permission to do so' (2007:113).

Parental relationships that support and encourage autonomy in important decisions and choices whilst providing guidance and encouragement appeared to promote independent yet trusting relationships. Trust within the family was important as it also appeared to promote self-confidence. Whilst parents of high educational aspirers did retain authority, for example, with the issuing of sanctions and boundaries, generally these were viewed as fair. In understanding the aspirations of the high educational aspirers then, it could be argued that it is the promotion of autonomy and independence, coupled with trusting relationships within families that contributes to students investing trust outside of the family, for example, within school.

\section{Discussion}

Whilst conceptualisations of social capital differ, underlying is the premise that social capital creates trust, i.e. that social capital increases with increased community engagement via the development of trusting and reciprocal relationships. Regular involvement generates greater degrees of trust between individuals and communities and this has positive benefits, in this 
case in terms of educational outcomes. In this research students appear to be accumulating social capital and seeking it, not as a social good but as a source for individual advantage and benefit. However, what is striking is that whilst conceptualizations of social capital see trust as a positive outcome, data appears to tentatively suggest that trust is a pre-requisite of the acquisition of social capital rather than the reverse. Trust, particularly institutional trust, appears to be important because it facilitates a student's willingness to accept the legitimacy of the educational system in terms of determining future lives but also because it fosters a willingness to become actively involved with the school. Of course there are many factors that will impact and interact with the acquisition of trust that are not captured in this small scale study. The role of teachers, for example, is not clear. However data does appear to tentatively suggest that the direction of causality in terms of social capital and trust is perhaps reversed and that it is trust, in the first instance, that appears to matter.

Trust (and its degree), be it in terms of relationships with family, institutions such as schools or communities, appears to facilitate willingness for civic engagement and this engagement in turn appears to promote social capital i.e. it facilitates its further acquisition. Trust is suggestive as under pinning the acquisition and, if so, is therefore the foundation stone on which individual people build. Conceptualising social capital in this way makes it extremely useful for explaining why differences in educational aspirations and ambitions or community involvement differ, even when other social characteristics such as class are held constant. It is also useful in that it enables students to be understood as active agents in their own right, generating their own social capital, rather than viewed as dependents of family social capital. However, understanding the process for trust in the first instance is less clear. Whilst a direct 
link with aspirations can also only be suggestive, data does appear to suggest a relationship with trust in the broad sense and ambitions for university.

High educational aspirers value education greatly and trust that their own hard work and effort is what will ensure their future educational success. One of the main ways that 'high educational aspirers' could be distinguished from other students within school was their willingness to participate and be involved in school at an institutional level. Whilst many students across the school participate in a variety of ways in school life such as for example: charity and fund raiser days; talent shows and school plays as well as sporting events etc., these activities are somewhat different in that they tend to be collective, social and fun activities in which the whole school or sub-groups participate. High educational aspirers, in contrast to other students, also participate on a level that appears to present them as active agents of the school rather than simply members of the school, for example through the school council. These tend to be more individualistic activities. Girls articulate a desire to be involved as they feel they should but also because they see it as advantageous to do so. Theoretical explanations which might account for high educational aspirers' contribution and involvement in school may possibly attribute this to increased or accumulating levels of social capital and, certainly there is much utility in the concept in terms of the Putman's ideas surrounding civic engagement and social trust. In many ways, the girls included here could be considered as attempting to 'bridge' their social space.

Social capital within education is important as it appears to reinforce positive attitudes towards education as well as promoting a sense of individual autonomy. This research offers no clear empirical evidence of the role that parents' social capital (as conceptualized 
theoretically) has in shaping educational aspirations. However, data does suggests that young people are able to accumulate social capital in their own right (based on current definitions) and do not rely solely on their parents'. This is consistent with Morrow's (1999) finding. Self acquisition was demonstrated by high educational aspirers' keenness to be pro-active agents rather than passive recipients within their education. In explaining why this may be so, it is trust that appears to have a role. Students who appear to trust in school and the people who work there also expressed the most enthusiasm to participate within it. Trust is implicit in high educational aspirers' belief in meritocracy and is demonstrated in terms of student rationalisation i.e. that involving oneself will be worth it and that their hard work will pay off in terms of their educational outcomes. More broadly, trust may explain why civic engagement is so varied i.e. it explains why an individual may help out at school or at work but, not in their neighbourhood. In determining why some students are more trusting than others, a combination of factors appear important but in this research, trust in the educational context appears to relate to a student's ability to believe in the principles of meritocracy, i.e. that effort is worth it, relative to the rewards received, in terms of the goals they have and is interconnected to a student's desire to involve herself in the political and organisational life of the school.

Whilst gender is not the focus for this paper, it is worth noting that the influence of class cannot be considered in isolation of the important ways that gender embodies both meaning and a frame of reference in the subjective shaping of aspirations. Neo-liberal discourse proclaims a 'can do' era, yet 'can do' is still constrained by gender. For the girls in this study gender appears to be negotiated and compensated for, through the acquisition of 'capitals' (for a more in-depth discussion of gender see Anon, 2009). The data presented in this research appears to cautiously suggest that students are able to generate social capital in their 
own right and both Putnam (2000) and Coleman's (1987) conceptualisation of social capital are useful in considering the young women presented here. However, whilst the paper cannot establish the strength of this capital it does suggests that trust appears as a pre-requisite for acquiring and generating social capital as opposed to the other way round. Whilst connections and associations between individuals and organisations may well be limited to those within one's social landscape, trust in the first instance does not limit that landscape in social terms (particularly when considered within the educational context). Whilst parental social capital will undoubtedly have positive consequences for a student's education, a lack of social capital does not appear necessarily detrimental to some students' educational values, attitudes and aspirations as theory might appear to imply. Some at least are able to create capital in their own right.

\section{Notes:}

In carrying out this research full ethical clearance was sought and all guidelines complied with. 


\begin{tabular}{|c|c|c|c|c|c|}
\hline Name & Set & $\begin{array}{l}\text { Parental } \\
\text { occupation }\end{array}$ & $\begin{array}{l}\text { Parents/family educational } \\
\text { Background }\end{array}$ & Post $16 / 18$ outcome & EMA \\
\hline Wafa & 3 & $\begin{array}{l}\mathrm{F}-\text { taxi driver } \\
\mathrm{M} \text { - housewife }\end{array}$ & No one in family & Stayed on at current school - applied to London university & $\mathrm{N} / \mathrm{K}$ \\
\hline Nasrat & 3 & $\begin{array}{l}\mathrm{F}-\text { taxi driver } \\
\mathrm{M} \text { - housewife }\end{array}$ & Older brother attending college & $\begin{array}{l}\text { Stayed on at current school - applied to local university - } \\
\text { outcome not known }\end{array}$ & FSM \\
\hline Deborah & 1 & $\begin{array}{l}\mathrm{F} \text { - Cleaner } \\
\text { M- Cleaner }\end{array}$ & $\begin{array}{l}\text { Neither parent continued education. Much older } \\
\text { step-sister attended university but no contact } \\
\text { (lives in USA) }\end{array}$ & Final year local university & Yes \\
\hline Emily & 1 & $\begin{array}{l}\mathrm{F}-\text { works with glass } \\
\mathrm{M} \text { - quit smoking } \\
\text { counsellor }\end{array}$ & $\begin{array}{l}\text { Father - did not continue } \\
\text { Mother - not known }\end{array}$ & Studying Brighton university & $\mathrm{N} / \mathrm{K}$ \\
\hline Stephanie & 1 & Brother - builder & $\begin{array}{l}\text { Brother did not continue } \\
\text { Rest of family not known }\end{array}$ & Final year Brighton University & $\mathrm{N} / \mathrm{K}$ \\
\hline Fatima & 4 & $\mathrm{M}$ - does not work & $\begin{array}{l}\text { Mother did not continue } \\
\text { Uncle went to college }\end{array}$ & Graduated St Mary's London, 2011 & Yes \\
\hline Sahara & $\begin{array}{l}\text { Year } \\
12\end{array}$ & Not known & Not known & Graduated local university 2011 & $\mathrm{~N} / \mathrm{K}$ \\
\hline Lotte & $\begin{array}{l}\text { Year } \\
12\end{array}$ & Not known & $\begin{array}{l}\text { Father attending college in evenings with aim to } \\
\text { go to university } \\
27\end{array}$ & $\begin{array}{l}\text { Left to study at local college at end of year } 12 \text { - outcome not } \\
\text { known }\end{array}$ & No \\
\hline
\end{tabular}


Social Capital and Educational Aspirations

\section{References}

Ball, S. J. (2003), Class Strategies and the Education Market: The Middle Classes and Social Advantage, Routledge Falmer.

Bogenschnieder, K. (1997), Parental Involvement in Adolescent Schooling: A Proximal Process with Transcontextual Validity, Journal of Marriage and Family, Vol. 59, Issue 3 (Aug.).

Bourdieu, P. The Forms of Social Capital Halsey, in A.H., Lauder, H., Brown, P., Stuart Wells, editors, (1997), Education, Culture, Economy, Society, Oxford University Press.

Cohen, L.; Manion, L. and Morrison, K. (2001), Research Methods in Education, Fifth Edition, Routledge Falmer.

Coleman, J. S. (1987), Families and Schools, Educational Researcher, Vol. 16, (6).

Coleman, J. S. (1988), Social Capital in the Creation of Human Capital, The American Journal of Sociology, Vol. 94, Supplement: Organisations and Institutions: Sociological and Economic Approaches to the Analysis of Social Structure.

Crompton, R. (1998), Class and Stratification: An Introduction to Current Debates, Second Edition, Polity Press.

Croll, P. (2004), Families, Social Capital and Educational Outcomes, British Journal of Educational Studies, Vol. 52, No. 4, (Dec.).

DfES, (2003), Every Child Matters: Change for Children in Schools, HM Government.

DfES, (2005), Extended Schools: Building On Experience, HM Government.

DfES, (2007), NEET Statistics: Quarterly Brief, HM Government. 
Social Capital and Educational Aspirations

DiMaggio, P. (1982), Cultural Capital and School Success: The Impact of Status Culture Participation on the Grades of U.S. High School Students, American Sociological Review, Vol. 47, No. 2.

English Indices of Deprivation: Indicators of deprivation for use in school funding:

September (2004):

http://www.teachernet.gov.uk/_doc/10254/Technical\%20Review\%20of\%20Deprivation\% 20Indicators $\% 20($ Sept $\% 2006) \% 20$ Full $\% 20$ draft.doc

Edwards, B., Foley, M.W. (2001), Review: Much Ado about Social Capital, Contemporary Sociology, Vol. 30, No. 3.

Anon, (2009)

Gewirtz, S.;Dickson, M.; Power, S.; Halpin, D. and Whitty, G. (2005), The Deployment of social Capital Theory in Educational Policy and Provision; the Case of Educational Action Zones in England, British Educational Research Journal, Vol. 31, No. 6, (Dec.).

Goldthorpe, J. H. (2007a), “Cultural Capital”: Some Critical Observations, Sociologica, Issue 2.

Grenfell, M.; James, D.; Hodkinson, P.; Reay, D. and Robbins, D. (1997) Acts of Practical Theory: Bourdieu and Education, Falmer Press.

Halsey, A. H.; Heath, A.F. and Ridge, J.M. (1980), Origins and Destinations: Families, Class, and Education in Modern Britain, Oxford,Clarendon Press.

Horvet, E. M.' Weininger, E.B.; Lauearu, A., (2003), From Social Ties to Social Capital: Class Differences in the Relations Between Schools and Parent Networks, American Educational Research Journal, Vol. 40, No. 2, pp 319-351. 
Social Capital and Educational Aspirations

Jenkins, R.(1992), Pierre Bourdieu, Revised Edition, London and New York, Routledege.

Lareau, A. Social-Class Differences in Family-School Relationships: The Importance of Cultural Capital, in Halsey, A.H; Lauder, H.; Brown, P and Stuart Wells, A Editors, 1997, Education, Culture, Economy, Society, Oxford University Press.

Li , C. and Kerpelman, J. (2007) Parental Influences on Young Women's Certainty about Their Career Aspirations, Sex Roles, 56, pp. $105-115$.

Morrow, V. (1999), Conceptualising Social Capital in Relation to the Well Being of Children and Young People: a Critical Review, The Sociological Review.

Ofsted (2006), Special Measures: Monitoring Inspection of “Southwell” Girls School, Dec.

Paton, K, (2007), Conceptualising 'Choice'; A review of the theoretical literature, ESRC Non-Participation in HE Project Series, Working Paper 5

Patton, M., (2002), Qualitative Research and Evaluation Methods, London: Sage

Putman, R. (2000), Bowling Alone: The Collapse and Revival of American Community, New York: London, Simon and Schuster.

Reay, D. (2005), Doing the Dirty Work of Social Class? Mothers' Work in Support of their Children's Schooling, Sociological Review, pp. $104-115$.

Rose, D. and Pevalin, D. (2002) The NS-SEC described. In Rose D and Pevalin D (eds) A Researchers Guide to the National Statistics Socio-economic Classification London: Sage.

U.S. Department of Education, (2003), No Child Left Behind: A Parents' Guide, 